\title{
Deletion of growth hormone receptor gene but not visceral fat removal decreases expression of apoptosis-related genes in the kidney_potential mechanism of lifespan extension
}

\author{
Adam Gesing • Michal M. Masternak • \\ Feiya Wang • Malgorzata Karbownik-Lewinska • \\ Andrzej Bartke
}

Received: 7 July 2010/Accepted: 2 March 2011 /Published online: 23 March 2011

(C) The Author(s) 2011. This article is published with open access at Springerlink.com

\begin{abstract}
Mice homozygous for the targeted disruption of the growth hormone $(\mathrm{GH})$ receptor $(\mathrm{Ghr})$ gene $(\mathrm{GH}$ receptor knockout; GHRKO; KO) are hypoinsulinemic, highly insulin sensitive, normoglycemic, and longlived. Visceral fat removal (VFR) is a surgical intervention which improves insulin signaling in normal $(\mathrm{N})$ mice and rats and extends longevity in rats. We have previously demonstrated decreased expression level of certain pro-apoptotic genes in skeletal muscles and
\end{abstract}

A. Gesing - M. M. Masternak · F. Wang - A. Bartke Department of Internal Medicine, Geriatrics Research, Southern Illinois University School of Medicine, 801 N Rutledge St., Room 4389,

Springfield, IL 62702-4910, USA

A. Gesing $(\bowtie) \cdot$ M. Karbownik-Lewinska

Department of Oncological Endocrinology,

Chair of Endocrinology and Metabolic Diseases,

Medical University of Lodz,

Zeligowski St., No 7/9,

90-752 Lodz, Poland

e-mail: adges7@wp.pl

e-mail: adges7@yahoo.com

M. M. Masternak

Institute of Human Genetics, Polish Academy of Sciences,

Strzeszynska St., No 32,

60-479 Poznan, Poland

M. Karbownik-Lewinska

Department of Endocrinology and Metabolic Diseases,

Polish Mother's Memorial Hospital-Research Institute,

Rzgowska St., No 281/289,

93-338 Lodz, Poland suggested that this may contribute to the regulation of longevity in GHRKO mice. Alterations in apoptosisrelated genes expression in the kidneys also may potentially lead to lifespan extension. In this context, we decided to examine the renal expression of the following genes: caspase-3, caspase-9, caspase-8, bax, bad, bcl-2, Smac/DIABLO, Apaf-1, p53, and cytochrome $\mathrm{cl}$ (cyc1) in male GHRKO and $\mathrm{N}$ mice subjected to VFR or sham surgery, at approximately 6 months of age. The kidneys were collected 2 months after VFR. As a result, caspase-3, caspase-9, and bax expressions were decreased in $\mathrm{KO}$ mice as compared to $\mathrm{N}$ animals. Expressions of Smac/DIABLO, caspase-8, bcl-2, bad, and p53 did not differ between KOs and $\mathrm{N}$ mice. VFR did not change the expression of the examined genes in $\mathrm{KO}$ or $\mathrm{N}$ mice. In conclusion, endocrine abnormalities in GHRKO mice result in decreased expression of pro-apoptotic genes and VFR did not alter the examined genes expression in $\mathrm{N}$ and KO mice. These data are consistent with a model in which alterations of $\mathrm{GH}$ signaling and/or insulin sensitivity lead to increased lifespan mediated by decreased renal expression of pro-apoptotic genes.

Keywords Apoptosis · GHRKO mice · Kidney · Gene expression $\cdot$ Caspases $\cdot$ Visceral fat removal

\section{Introduction}

Growth hormone $(\mathrm{GH})$ receptor/GH binding protein knockout mice (GHRKO; KO) are $\mathrm{GH}$ resistant due 
to targeted disruption of the $\mathrm{GH}$ receptor/GH binding protein (Ghr/bp) gene (Zhou et al. 1997). These mice are insulin sensitive and live longer than their normal (N) siblings, and are characterized by reduced weight and body size, not detectable concentration of $\mathrm{GH}$ receptor, high level of serum $\mathrm{GH}$, greatly reduced plasma levels of IGF-I and insulin, and low or normal glucose (Bartke and Brown-Borg 2004; Bartke et al. 2002; Coschigano 2006; Coschigano et al. 2000; 2003; Harper et al. 2006; Kopchick and Laron 1999; Liu et al. 2004; Zhou et al. 1997). Moreover, GHRKO mice have improved oxidative stress resistance and reduced oxidative damage (Bartke and Brown-Borg 2004; Salmon et al. 2005; Sun et al. 2009) with lower incidence and delayed onset of fatal neoplastic diseases (Ikeno et al. 2009).

Visceral fat removal (VFR) is a surgical intervention which has been reported to improve insulin signaling in $\mathrm{N}$ mice and rats and extend longevity in rats (Barzilai et al. 1999; Muzumdar et al. 2008; Shi et al. 2007), thus mimicking the effects of calorie restriction (CR). It is known that adipose tissue, through the production of pro-inflammatory cytokines (tumor necrosis factor- $\alpha$, interleukin-6, interleukin$1 \beta)$ may cause the alterations in insulin sensitivity leading to the insulin resistance (Fasshauer and Paschke 2003; Lagathu et al. 2003; Zhang et al. 2001). Moreover, some of these cytokines could induce apoptosis (Murata et al. 2010; Sishi and Engelbrecht 2011). In contrast, Holland et al. (2011) have recently demonstrated that adiponectin, an adipose tissue hormone which is known to improve insulin sensitivity, exert anti-inflammatory effects, and promote cell survival, may exert anti-apoptotic effects as well. These effects are caused by stimulation of ceramidase activity, and as a result of that, enhanced ceramide catabolism and formation of its anti-apoptotic metabolite-sphingosine-1-phosphate (Holland et al. 2011). Interestingly, the long-living GHRKO mice have been shown to have increased plasma levels of adiponectin (Berryman et al. 2004). Thus, it is not clear what over-riding effect VFR might have in the GHRKO mice.

Apoptosis is involved in the regulation of age-related functional alterations and longevity. Two central apoptotic signaling pathways are known: intrinsic (mitochondrial) (involving p53, bax, cytochrome c, and caspase-9, among others) - initiated by different factors within the cell (Boatright and Salvesen 2003;
Budihardjo et al. 1999; Jin and El-Deiry 2005), and extrinsic (death receptor) pathway (involving caspase8) (Boatright and Salvesen 2003). In spite of its wellknown benefits, leading to removal of abnormal cells, the role of apoptosis in longevity regulation is still unclear. Deletion of GH receptor decreased the expression level of some (caspase-3, caspase-9, bax, and Smac/DIABLO) but not all apoptosis-related genes in skeletal muscles, and we hypothesized that these alterations may play a role in the regulation of longevity in these knockout mice (Gesing et al. 2011). Interestingly, the double mutants produced by crossing mice with caspase-3 gene deletion (casp3-/-) and mice harboring the congenital polycystic kidney (cpk) mutation lived longer than control cpk animals (Tao et al. 2008). As apoptosis appears to increase in the normal aging kidney (Miyazawa et al. 2009) and pathological changes in kidneys are a very common cause of death in aging mice (Barton et al. 2000; Doi et al. 1988; Zheng et al. 2004), we decided to continue the study of apoptotic processes in the kidney of longlived GHRKO mice. In the present study, we have examined the renal expression levels of the following apoptosis-related genes: caspase-3, caspase-9, caspase8, bax, bad, bcl-2, Smac/DIABLO, Apaf-1, p53, and cytochrome $\mathrm{c} 1$ (cyc1) in $\mathrm{KO}$ and $\mathrm{N}$ mice after VFR or sham surgery.

\section{Materials and methods}

Animals, visceral fat removal, and assessment of blood chemistry

The normal and GHRKO mice used in the present study were produced in our breeding colony, developed using animals kindly provided by Dr. J.J. Kopchick (Ohio University). Animals were produced by mating knockout $(-/-)$ males with heterozygous $(+/-)$ females. Normal (+/-) and GHRKO animals $(-/-)$ were separated by phenotypic characteristics. All animal procedures were approved by the Laboratory Animal Care and Use Committee at the Southern Illinois University School of Medicine (Springfield, IL). The mice were housed under temperature- and light-controlled conditions $\left(22 \pm 2^{\circ} \mathrm{C}, 12 \mathrm{~h}\right.$ light $/ 12 \mathrm{~h}$ dark cycle) and fed Lab Diet 5001 chow (PMI Nutrition International, Richmond, IN) containing $4.5 \%$ fat and $23.4 \%$ protein. At the age of approxi- 
renal caspase-3 mRNA expression
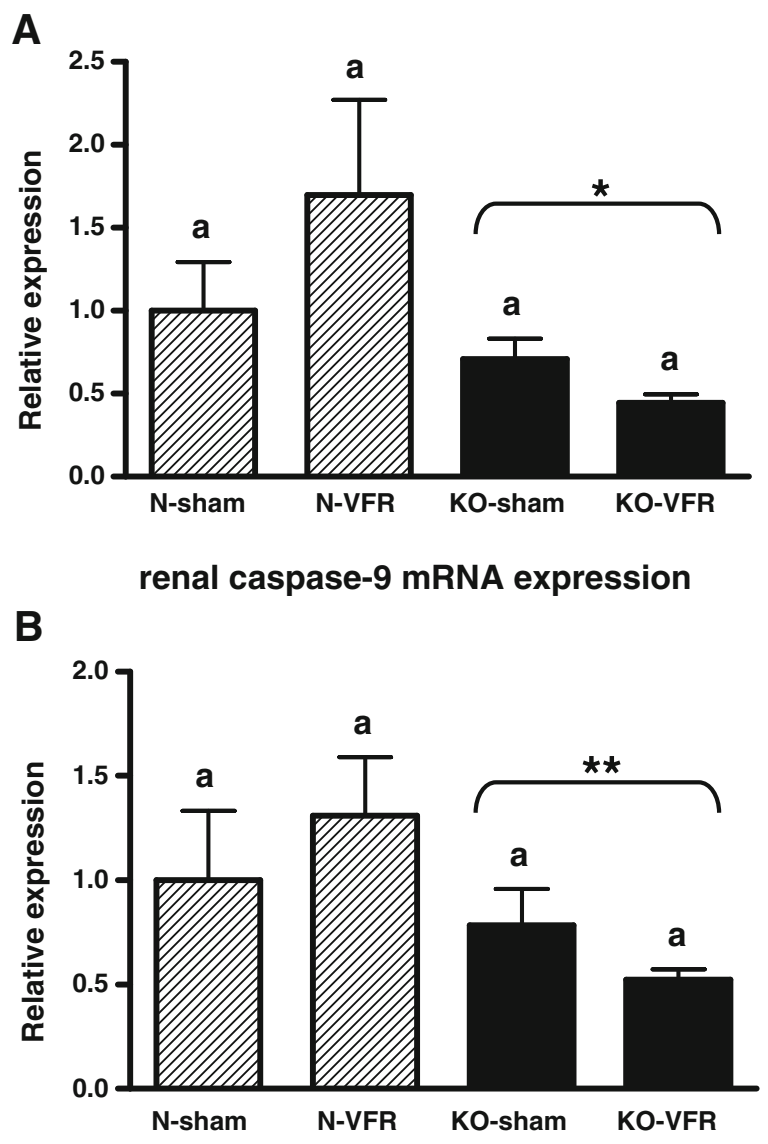

renal bax mRNA expression

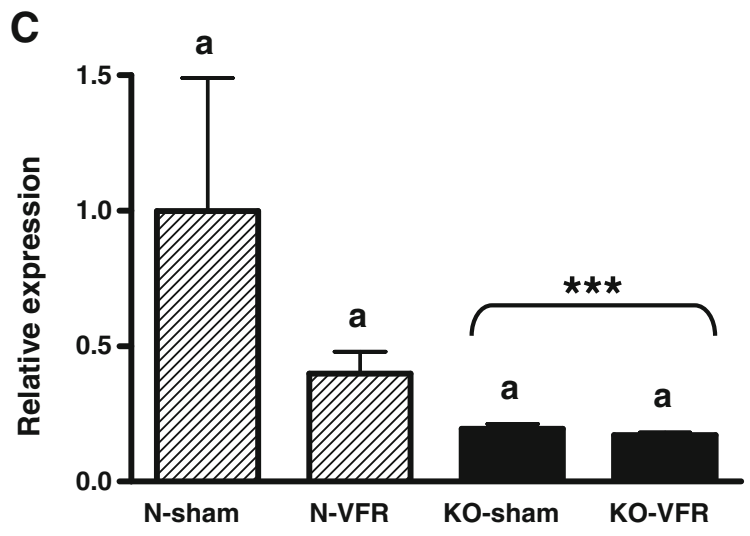

mately 6 months, 43 normal and GHRKO male mice were grouped according to average body weight within the phenotype, and divided into four experimental groups: normal sham-operated (N-sham; 11 animals), normal subjected to visceral fat removal (N-
Fig. 1 Caspase-3 (A), caspase-9 (B), and bax (C) mRNA expression in the kidney of normal $(N)$ and growth hormone receptor/binding protein knockout (GHRKO; KO) mice shamoperated (sham) or subjected to visceral fat removal (VFR). The data from RT-PCR were normalized by the housekeeping gene $\beta 2$-microglobulin and expressed as the relative expression. Values are means \pm SEM. $a$-values that share the same letter in the superscript are not significantly different. ${ }^{*} p=0.027$ vs. $\mathrm{N}$ mice (the significance for genotype), $* * p=0.043$ vs. $\mathrm{N}$ mice (the significance for genotype), $* * * p=0.042$ vs. $\mathrm{N}$ mice (the significance for genotype)

VFR; 11 animals), GHRKO sham-operated (KOsham; 10 animals), and GHRKO subjected to visceral fat removal (KO-VFR; 11 animals). The animals were anesthetized with ketamine/xylazine, shaved, and prepared in the usual sterile fashion. Mice were supplied with ibuprofen in drinking water starting 2 days before and up to 3 days after the surgery. Tap water was available at all times to all animals. In the VFR group, the epididymal fat pads were removed using blunt dissection through a vertical midline incision. Perinephric fat pads were removed via flank incisions. We removed as much epididymal or perinephric fat as was possible without compromising blood supply to the testes and to the adrenals. For sham operations, the abdominal cavity and both sides of the back were incised, and the visceral fat was mobilized but not removed. Two months after VFR or sham operations, the animals were fasted overnight, and fasting glucose levels were measured in blood collected from the tail vein using OneTouch Ultra glucometer (Life Scan, Milpitas, CA). Next, the mice were anesthetized using ketamine/xylazine, bled by cardiac puncture, and euthanized by decapitation. Kidneys were rapidly collected, quickly frozen on dry ice, and stored at $-80^{\circ} \mathrm{C}$ until processed. Plasma obtained from blood collected by cardiac puncture was used for assessment of insulin using Rat/Mouse Insulin ELISA (Linco Research Inc., St. Charles, $\mathrm{MO}$ ) following manufacturer's protocols.

RNA extraction and complementary DNA transcription

The RNA was extracted from the homogenates of kidneys using guanidinium thiocyanate-phenolchloroform method based on Chomczynski-Sacchi procedure (1987). RNA quantity and quality were analyzed on $1.5 \%$ agarose gel using electrophoresis. Potentially contaminating residual genomic DNA was 
eliminated using deoxyribonuclease I (Promega, Madison, WI). Reverse transcription was performed and complementary DNA was synthesized using an iScript cDNA Synthesis Kit (Bio-Rad Laboratories, Hercules, CA) in accordance with manufacturer's instruction.

Real-time polymerase chain reaction

The real-time polymerase chain reaction (RT-PCR) was carried out using the Smart Cycler instrument (Cepheid, Sunnyvale, CA) with iQ SYBR Green Supermix (Bio-Rad Laboratories, Hercules, CA). The three steps of the PCR included: denaturation at $94^{\circ} \mathrm{C}$ for $2 \mathrm{~min}$, annealing at $62^{\circ} \mathrm{C}$ for $30 \mathrm{~s}$ with fluorescence reading, and extension at $72^{\circ} \mathrm{C}$ for $30 \mathrm{~s}$. In addition, a melting curve was done for each reaction to evaluate the potential of nonspecific products. $\beta_{2}$-Microglobulin (B2M) was used as a housekeeping gene; it has been previously validated in our laboratory as the most appropriate gene for normalizing the data (Masternak et al. 2006). The gene expression was assessed by measurement of steady state levels of mRNA. Relative expression from RT-PCR was calculated from the equation $2^{A-B} /$ $2^{C-D}$ (where $A=$ cycle threshold [Ct] number for the gene of interest in the first control sample, $B=\mathrm{Ct}$ number for the gene of interest in the analyzed sample, $C=\mathrm{Ct}$ number for the housekeeping gene in the first control sample, and $D=\mathrm{Ct}$ number for housekeeping gene in the analyzed sample). The first control was expressed as 1.00 by this equation, and all other samples were calculated in relation to this value. Then, the results in the control group (N-sham) were averaged, and all other outputs were divided by the mean value of the relative expression in the control group to yield the fold change of the expression of genes of interest compared to the control group.

For RT-PCR the following primers were used [gene bank sequence number by each forward primer]:

B2M: forward [NM_009735]: 5'-aagtatactcacgc caccca, backward: 5'-aagaccagtccttgctgaag; caspase-3: forward [NM_009810]: 5'-tgcagcatgct gaagctgta, backward: 5'-gagcatggacacaatacacg; caspase-9: forward [NM_015733]: 5'-agcagagag tagtgaagctg, backward: 5'-acacagacatcatgagctcc; caspase-8: forward [AJ007749]: 5'-accgagatcctgt gaatgga, backward: 5'-tgetttccettgttcctcct; bax: forward [NM_007527]: 5'-ccaccagctctgaa cagatc, backward: 5'-cagcttcttggtggacgcat; bad: forward [NM_007522]: 5'-agagtatgttcca gatcccag, backward: 5'-gtcctcgaaaagggctaagc; bcl-2: forward [NM_009741]: 5'-tgggatgcetttgtg gaact, backward: 5'-gagacagccaggagaaatca; Smac/DIABLO: forward : [NM_023232] 5'aagagctgcaccagaaagca, backward: $5^{\prime}$-tctgactgt caatggcagga;

Table 1 Relative gene expression (as percent deviation from control group- N-sham) in kidneys of normal (N) and growth hormone receptor/binding protein knockout (KO) mice sham-operated (sham) or subjected to visceral fat removal (VFR)

\begin{tabular}{|c|c|c|c|c|c|c|c|c|c|c|}
\hline Gene & $\begin{array}{l}\text { N-sham } \\
\text { (A) }\end{array}$ & $\begin{array}{l}\text { N-VFR } \\
\text { (B) }\end{array}$ & $\begin{array}{l}\text { KO-sham } \\
\text { (C) }\end{array}$ & $\begin{array}{l}\text { KO-VFR } \\
\text { (D) }\end{array}$ & $\begin{array}{l}p \text { value, } \\
\text { A vs. } \mathrm{B}\end{array}$ & $\begin{array}{l}p \text { value, } \\
\mathrm{C} \text { vs. D }\end{array}$ & $\begin{array}{l}p \text { value, } \\
\text { A vs. C }\end{array}$ & $\begin{array}{l}p \text { value, } \\
\mathrm{B} \text { vs. } \mathrm{D}\end{array}$ & $\begin{array}{l}p \text { value, } \mathrm{AB} \\
\text { vs. } \mathrm{CD}(\mathrm{N} \\
\text { vs. } \mathrm{KO})\end{array}$ & $\begin{array}{l}p \text { value, AC } \\
\text { vs. BD (sham } \\
\text { vs. VFR) }\end{array}$ \\
\hline Caspase-3 & $100 \pm 29 \%$ & $169 \pm 57 \%$ & $70 \pm 12 \%$ & $44 \pm 5 \%$ & NS & NS & NS & NS & 0.027 & NS \\
\hline Caspase-9 & $100 \pm 33 \%$ & $131 \pm 28 \%$ & $78 \pm 17 \%$ & $52 \pm 5 \%$ & NS & NS & NS & NS & 0.043 & NS \\
\hline bax & $100 \pm 49 \%$ & $40 \pm 8 \%$ & $19 \pm 2 \%$ & $17 \pm 1 \%$ & NS & NS & NS & NS & 0.042 & NS \\
\hline Apaf-1 & $100 \pm 12 \%$ & $83 \pm 11 \%$ & $203 \pm 51 \%$ & $197 \pm 17 \%$ & $\mathrm{NS}$ & NS & NS & 0.034 & $<0.001$ & NS \\
\hline cyc1 & $100 \pm 10 \%$ & $92 \pm 10 \%$ & $207 \pm 39 \%$ & $192 \pm 19 \%$ & NS & NS & 0.008 & 0.012 & $<0.001$ & NS \\
\hline Smac/DIABLO & $100 \pm 28 \%$ & $94 \pm 13 \%$ & $84 \pm 14 \%$ & $67 \pm 5 \%$ & NS & NS & NS & NS & NS & NS \\
\hline caspase- 8 & $100 \pm 10 \%$ & $92 \pm 8 \%$ & $120 \pm 14 \%$ & $108 \pm 9 \%$ & NS & NS & NS & NS & NS & NS \\
\hline bcl-2 & $100 \pm 44 \%$ & $77 \pm 16 \%$ & $83 \pm 24 \%$ & $59 \pm 10 \%$ & NS & NS & NS & NS & NS & NS \\
\hline bad & $100 \pm 28 \%$ & $99 \pm 16 \%$ & $89 \pm 16 \%$ & $59 \pm 5 \%$ & NS & NS & NS & NS & NS & NS \\
\hline p53 & $100 \pm 26 \%$ & $115 \pm 19 \%$ & $123 \pm 28 \%$ & $107 \pm 12 \%$ & NS & NS & NS & NS & NS & NS \\
\hline
\end{tabular}

Values are means \pm SEM

$N S$ no significant 
Apaf-1: forward [AF064071]: 5'-tacaacgctctgcta cacga, backward: 5'-cacacagcactgtccttaca;

p53: forward [AF151353]: 5'-tcacagtcggatat cagcct, backward: 5'-acactcggagggettcactt;

cytochrome c1: forward [NM_025567]: 5'-tacaag caggtgtgctcttc, backward: 5'-atcattagggccatcctgga.

\section{Statistical analysis}

The data are expressed as mean \pm standard error of the mean (SEM). To evaluate the effects of the genotype and surgical intervention, two-way analysis of variance, was used. A $t$ test was used to evaluate the effects of surgery within genotypes and genotypes within surgical interventions. A value of $p<0.05$ was considered significant. All statistical calculations were conducted using SPSS version 17.0 (SPSS, Chicago, IL) with $\alpha=0.05$. All graphs were made using Prism 4.02 (GraphPad Software, San Diego, CA).

\section{Results}

Expression of caspase-3 gene was decreased in kidneys of $\mathrm{KO}$ as compared to normal $(\mathrm{N})$ mice $(p=0.027)$ (Fig. 1A, Table 1). Similarly, the caspase-9 (Fig. 1B, Table 1) and bax (Fig. 1C, Table 1) mRNA levels were decreased in KOs in comparison to $\mathrm{N}$ animals $(p=0.043$, $p=0.042$, respectively). In contrast, the mRNA levels of Apaf-1 (Fig. 2A, Table 1) and cyc1 (Fig. 2B, Table 1) were increased in knockouts as compared to $\mathrm{N}$ mice ( $p<0.001$ both). Moreover, the level of Apaf-1 mRNA was up-regulated in KOs subjected to VFR (KO-VFR) in comparison to $\mathrm{N}$ mice after VFR ( $p=$ 0.034) (Fig. 2A, Table 1). Additionally, there was increased cycl expression in KO-sham and KO-VFR mice, in comparison to the corresponding $\mathrm{N}$ mice ( $p=0.008, p=0.012$, respectively) (Fig. 2B, Table 1 ). Expression of Smac/DIABLO (Fig. 3A, Table 1), caspase-8 (Fig. 3B, Table 1), bcl-2 (Fig. 3C, Table 1), bad (Fig. 3D, Table 1), and p53 (Fig. 3E, Table 1) in $\mathrm{KO}$ mice did not differ from values measured in $\mathrm{N}$ animals. VFR did not change the expression of the examined genes in the kidneys of $\mathrm{KO}$ or $\mathrm{N}$ mice (Figs. 1, 2, and 3, Table 1).

Glucose levels were increased in GHRKO mice after VFR in comparison to sham-operated knockouts renal Apaf-1 mRNA expression
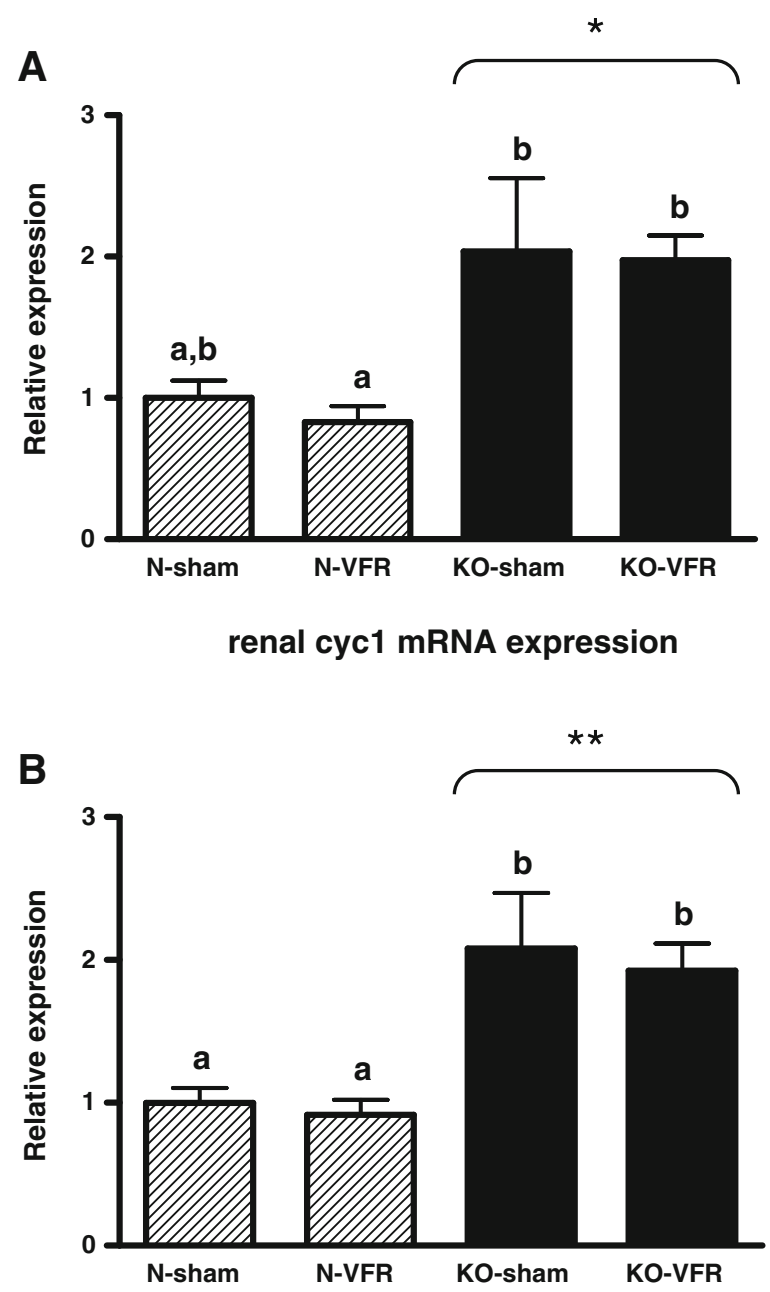

Fig. 2 Apaf-1 (A) and cyc1 (B) mRNA expression in the kidney of normal $(N)$ and growth hormone receptor/binding protein knockout $(K O)$ mice sham-operated (sham) or subjected to visceral fat removal $(V F R)$. The data from RT-PCR were normalized by the housekeeping gene $\beta 2$-microglobulin and expressed as the relative expression. Values are means \pm SEM. $a, b$ - values that do not share the same letter in the superscript are significantly different $(p<0.05) .{ }^{*} p<0.001$ vs. $\mathrm{N}$ mice (the significance for genotype), ${ }^{* *} p<0.001$ vs. $\mathrm{N}$ mice (the significance for genotype)

$(p=0.009)$, while in normal mice, there was a trend in the opposite direction, i.e., reduction of glucose after VFR (Fig. 4A). Moreover, there was a significant genotype/VFR interaction for glucose levels $(p=$ 0.016) (Fig. 4A). Interestingly, fasting insulin levels were significantly decreased after VFR in normal mice ( $p=0.019)$ (Fig. 4B). 
renal Smac/DIABLO mRNA expression

A

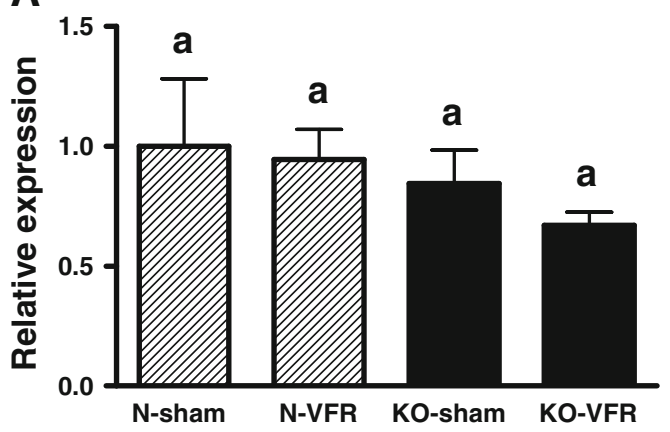

renal bcl-2 mRNA expression

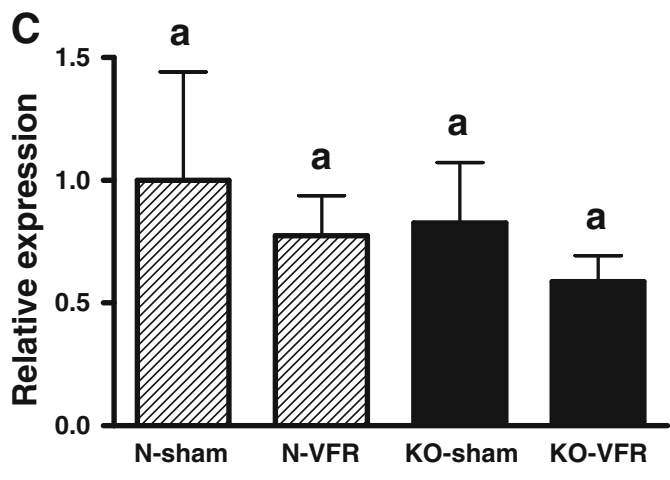

renal p53 mRNA expression

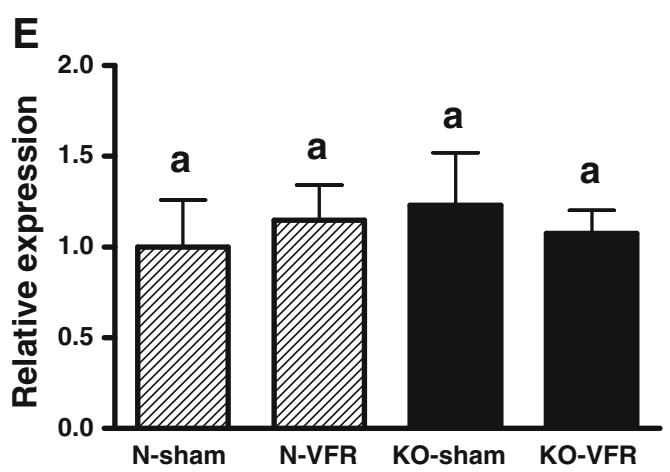

Fig. 3 Smac/DIABLO (A), caspase-8 (B), bcl-2 (C), bad (D), and p53 (E) mRNA expression in the kidney of normal $(N)$ and growth hormone receptor/binding protein knockout $(\mathrm{KO})$ mice sham-operated (sham) or subjected to visceral fat removal $(V F R)$. The data from RT-PCR were normalized by the

\section{Discussion}

The kidneys are organs which are strongly affected by aging (Percy et al. 2008; Yang and Fogo 2010) that may cause increased glomerulosclerosis, interstitial renal caspase-8 mRNA expression

B

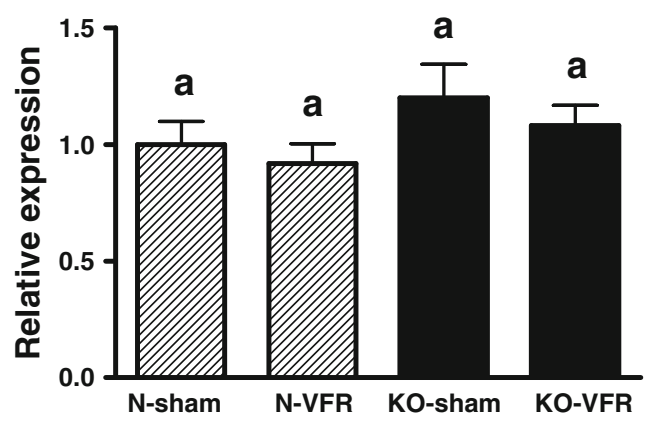

renal bad mRNA expression

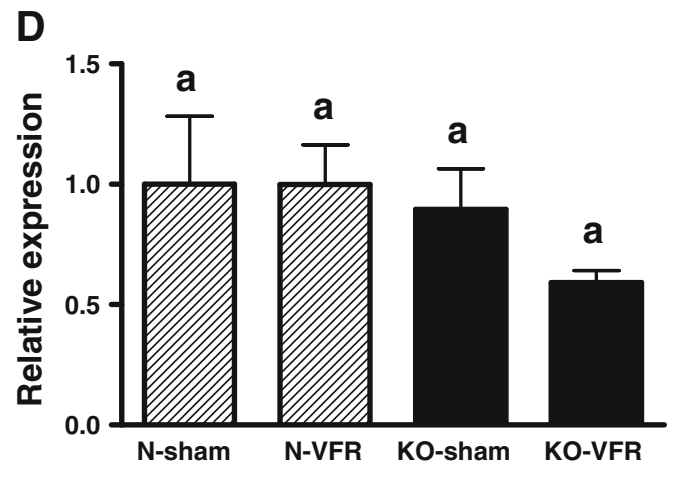

housekeeping gene $\beta 2$-microglobulin and expressed as the relative expression. Values are means \pm SEM. $a$-values that share the same letter in the superscript are not significantly different

fibrosis, tubular atrophy, and a loss of functional renal tissue, involving the number of nephrons and also glomeruli and tubules in the cortex. These histologic features may lead, among others, to increased renal vascular resistance and reduced renal plasma flow. 


\section{blood glucose}

A

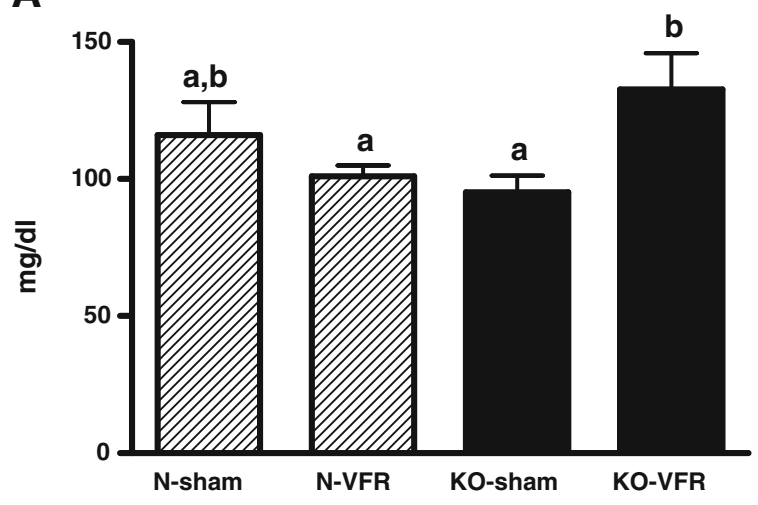

B

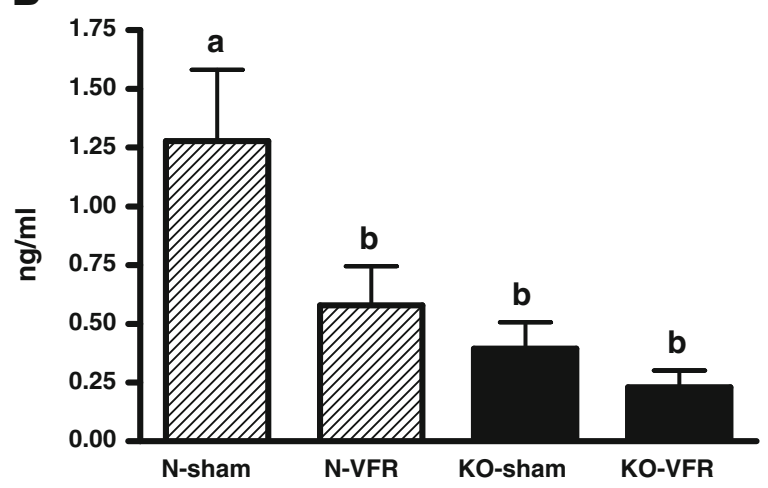

Fig. 4 Blood glucose (A) and plasma insulin (B) level in normal $(N)$ and growth hormone receptor/binding protein knockout $(K O)$ mice sham-operated (sham) or subjected to visceral fat removal $(V F R)$. Values are means \pm SEM. $a, b-$ values that do not share the same letter in the superscript are significantly different $(p<0.05)$

The process of apoptosis that is involved in the regulation of development and health maintenance, has not been, as yet, completely examined in longlived GHRKO mice. It is known that the level of apoptosis increases during aging. Miyazawa et al. (2009) showed that protein level of cytochrome c, the leakage of which from mitochondria to the cytoplasm is considered as one of markers of apoptosis, increased 3.5-fold in kidney of 24-month-old compared to 2-month-old $\mathrm{C} 57 \mathrm{BL} / 6 \mathrm{~J}$ mice. Thus, the suppression of apoptosis would seem to be beneficial physiological effect in the context of prolonged lifespan.

As was mentioned above, we observed decreased expression of certain pro-apoptotic genes (caspase-3, caspase-9, bax, and Smac/DIABLO) in skeletal muscles of KOs that may contribute to the regulation of longevity in these knockouts (Gesing et al. 2011). For all the abovementioned reasons, it was of interest to assess the expression of apoptosis-related genes in kidneys of GHRKO mice.

In the present study, the expression level of main effector (executioner) caspase-caspase-3 - was decreased in kidneys of GHRKO mice as compared to normal animals. This change may be considered as potentially beneficial for longevity extension in KOs because a change in the opposite direction, an increase in caspase-3 expression was reported in various pathological conditions. The increased expression of caspase- 3 has been reported in ischemic injury to kidney (Faubel and Edelstein 2005; Zhang et al. 2006). Moreover, the renal level of caspase-3 expression was markedly increased in polycystic kidney disease mice (Ali et al. 2000). The decreased caspase-3 expression in insulin-sensitive GHRKO mice may correspond to the observation that type 2 diabetic $d b / d b$ mice with a point mutation in the leptin receptor gene, leading to insulin resistance, among others (Moien-Afshari et al. 2008), have increased renal caspase-3 activity (Ghosh et al. 2009). Interestingly, the caspase inhibitor IDN-8050 slowed the disease progression in the Han:SPRD rat model of polycystic kidney disease (Tao et al. 2005).

In our present study, the mRNA level of caspase-9 was decreased in GHRKO mice. This change in caspase-9 expression also may be regarded as beneficial for these insulin-sensitive mice and consistent with the results of the study performed by Mishra et al. (2005) in which the authors demonstrated that high glucose increased caspase-9 activity in human mesangial cells.

The targeted disruption of the Ghr gene leads to decreased bax expression. It could be speculated that this change may be beneficial for GHRKO mice. It has been shown that $\beta$-catenin/Wnt signaling pathway may promote survival of epithelial cells in kidney after metabolic stress and this beneficial effect seems to be associated with inhibiting bax expression (Wang et al. 2009). In agreement with our results, the opposite-increased bax expression-was observed in renal cortex of diabetic $d b / d b$ mice (Ortiz et al. 1997) and also in cystic kidneys of congenital polycystic kidney disease mice (Ali et al. 2000). 
Unexpectedly, our study showed increased renal Apaf-1 expression in KO mice. This change seems to be difficult to explain in the context of results obtained in the present study for other apoptosisrelated genes. Nevertheless, it could be hypothesized that this up-regulation of Apaf-1 expression may have some beneficial implication in $\mathrm{KO}$ mice. It is known that Apaf-1 null mice have many developmental defects, and embryos lacking Apaf-1 show severe craniofacial deformation and retention of interdigital webs (Hickman and Helin 2002).

The cyc1 gene expression also was up-regulated in the kidneys of GHRKOs. However, it was previously reported that cytochrome c release may occur without loss of membrane potential, which normally precipitates opening of the permeability transition pores (Gross et al. 1999). Furthermore, cytochrome $\mathrm{c}$ is also involved in the electron transport chain. Thus, interpretation of the findings concerning cytochrome c gene expression is complicated by its multiple roles in physiological processes.

As mentioned previously, VFR may improve insulin signaling in $\mathrm{N}$ mice and rats and extend longevity in rats (Barzilai et al. 1999; Muzumdar et al. 2008; Shi et al. 2007). These alterations resemble the effects of calorie restriction (CR). In our present study, VFR did not alter the expression of the examined apoptosis-related genes in GHRKO and normal mice. These results seem to be consistent with our previous observation that CR did not affect apoptosis-related genes expression in GHRKO mice (Gesing et al. 2011).

After VFR, glucose levels were increased in GHRKO mice in comparison to sham-operated knockouts. Furthermore, VFR caused a decrease of fasting insulin levels in normal mice. These preliminary results show that VFR may promote insulin resistance in GHRKO mice, although it had the expected beneficial effect on insulin signaling in normal mice. Therefore, one could speculate that the role of visceral fat in the regulation of insulin signaling in the $\mathrm{N}$ mice and mice with deletion of growth hormone receptor may be different and needs further analysis.

In summary, endocrine abnormalities in GHRKO mice result in decreased expression of pro-apoptotic genes and VFR did not alter the examined genes expression in $\mathrm{N}$ and $\mathrm{KO}$ mice. These data are consistent with a model in which alterations of GH signaling and/or insulin sensitivity lead to increased lifespan mediated by decreased renal expression of pro-apoptotic genes. Nevertheless, further studies are still needed to determine how the expression levels of apoptosis-related genes in particular organs can contribute to the regulation of longevity.

Acknowledgments The present study was supported by NIA, AG 19899, U19 AG023122, AG31736, and AG032290; The Ellison Medical Foundation; Southern Illinois University School of Medicine; and Polish Ministry of Science and Higher Education N N401 042638.

Open Access This article is distributed under the terms of the Creative Commons Attribution Noncommercial License which permits any noncommercial use, distribution, and reproduction in any medium, provided the original author(s) and source are credited.

\section{References}

Ali SM, Wong VY, Kikly K, Fredrickson TA, Keller PM, DeWolf WE Jr, Lee D, Brooks DP (2000) Apoptosis in polycystic kidney disease: involvement of caspases. Am J Physiol Regul Integr Comp Physiol 278:R763-R769

Bartke A, Brown-Borg H (2004) Life extension in the dwarf mouse. Curr Top Dev Biol 63:189-225. doi:10.1016/ S0070-2153(04)63006-7

Bartke A, Chandrashekar V, Bailey B, Zaczek D, Turyn D (2002) Consequences of growth hormone (GH) overexpression and GH resistance. Neuropeptides 36:201208. doi: $10.1054 /$ npep. 2002.0889

Barton M, Lattmann T, d'Uscio LV, Luscher TF, Shaw S (2000) Inverse regulation of endothelin-1 and nitric oxide metabolites in tissue with aging: implications for the agedependent increase of cardiorenal disease. J Cardiovasc Pharmacol 36(5 Suppl 1):S153-S156

Barzilai N, She L, Liu B-Q, Vuguin P, Cohen P, Wang J, Rossetti L (1999) Surgical removal of visceral fat reverses hepatic insulin resistance. Diabetes 48:94-98. doi:10.2337/diabetes.48.1.94

Berryman DE, List EO, Coschigano KT, Behar K, Kim JK, Kopchick JJ (2004) Comparing adiposity profiles in three mouse models with altered GH signaling. Growth Horm IGF Res 14:309-318. doi:10.1016/j.ghir.2004.02.005

Boatright KM, Salvesen GS (2003) Mechanisms of caspase activation. Curr Opin Cell Biol 15:725-731. doi:10.1016/j. ceb.2003.10.009

Budihardjo I, Oliver H, Lutter M, Luo X, Wang X (1999) Biochemical pathways of caspase activation during apoptosis. Annu Rev Cell Dev Biol 15:269-290. doi:10.1146/ annurev.cellbio.15.1.269

Chomczynski P, Sacchi N (1987) Single-step method of RNA isolation by acid guanidinium thiocyanate-phenolchloroform extraction. Anal Biochem 162:156-159. doi:10.1016/0003-2697(87)90021-2

Coschigano KT (2006) Aging-related characteristics of growth hormone receptor/binding protein gene-disrupted mice. AGE 28:191-200. doi:10.1007/s11357-006-9004-x

Coschigano KT, Clemmons D, Bellush LL, Kopchick JJ (2000) Assessment of growth parameters and life span of GHR/ BP gene disrupted mice. Endocrinology 141:2608-2613 
Coschigano KT, Holland AN, Riders ME, List EO, Flyvbjerg A, Kopchick JJ (2003) Deletion, but not antagonism, of the mouse growth hormone receptor results in severely decreased body weights, insulin, and insulin-like growth factor I levels and increased lifespan. Endocrinology 144:3799-3810. doi:10.1210/en.2003-0374

Doi T, Striker LJ, Quaife C, Conti FG, Palmiter R, Behringer R, Brinster R, Striker GE (1988) Progressive glomerulosclerosis develops in transgenic mice chronically expressing growth hormone and growth hormone releasing factor but not in those expressing insulinlike growth factor-1. Am J Pathol 131:398-403

Fasshauer M, Paschke R (2003) Regulation of adipocytokines and insulin resistance. Diabetologia 46:1594-1603. doi: 10.1007/s00125-003-1228-z

Faubel S, Edelstein CL (2005) Caspases as drug targets in ischemic organ injury. Curr Drug Targets Immune Endocr Metabol Disord 5:269-287. doi:10.2174/1568008054863754

Gesing A, Masternak MM, Wang F, Lewinski A, KarbownikLewinska M, Bartke A (2011) Decreased expression level of apoptosis-related genes and/or proteins in skeletal muscles, but not in hearts, of growth hormone receptor knockout mice. Exp Biol Med 236:156-168. doi:10.1258/ ebm.2010.010202

Ghosh S, Khazaei M, Moien-Afshari F, Ang LS, Granville DJ, Verchere CB, Dunn SR, McCue P, Mizisin A, Sharma K, Laher I (2009) Moderate exercise attenuates caspase-3 activity, oxidative stress, and inhibits progression of diabetic renal disease in $d b / d b$ mice. Am J Physiol Renal Physiol 296:F700-F708. doi:10.1152/ajprenal.90548.2008

Gross A, McDonnell JM, Korsmeyer SJ (1999) BCL-2 family members and the mitochondria in apoptosis. Genes Dev 13:1899-1911

Harper JM, Salmon AB, Chang Y, Bonkowski M, Bartke A, Miller RA (2006) Stress resistance and aging: influence of genes and nutrition. Mech Ageing Dev 127:687-694. doi:10.1016/j.mad.2006.04.002

Hickman ES, Helin K (2002) The regulation of APAF1 expression during development and tumourigenesis. Apoptosis 7:167-171. doi:10.1023/A:1014370616864

Holland WL, Miller RA, Wang ZV, Sun K, Barth BM, Bui HH, Davis KE, Bikman BT, Halberg N, Rutkowski JM, Wade MR, Tenorio VM, Kuo M-S, Brozinick JT, Zhang BB, Birnbaum MJ, Summers SA, Scherer PE (2011) Receptormediated activation of ceramidase activity initiates the pleiotropic actions of adiponectin. Nat Med 17:55-63. doi: $10.1038 / \mathrm{nm} .2277$

Ikeno Y, Hubbard GB, Lee S, Cortez LA, Lew CM, Webb CR, Berryman DE, List EO, Kopchick JJ, Bartke A (2009) Reduced incidence and delayed occurrence of fatal neoplastic diseases in growth hormone receptor/binding protein knockout mice. J Gerontol A Biol Sci Med Sci 64:522-529. doi:10.1093/gerona/glp017

Jin Z, El-Deiry WS (2005) Overview of cell death signaling pathways. Cancer Biol Ther 4:139-163

Kopchick JJ, Laron Z (1999) Is the Laron mouse an accurate model of Laron syndrome ? Mol Genet Metab 68:232236. doi:10.1006/mgme.1999.2890

Lagathu C, Bastard JP, Auclair M, Maachi M, Capeau J, Caron M (2003) Chronic interleukin-6 (IL-6) treatment increased IL-6 secretion and induced insulin resistance in adipocyte: prevention by rosiglitazone. Biochem Biophys Res Commun 311:372-379. doi:10.1016/j.bbrc.2003.10.013

Liu JL, Coschigano KT, Robertson K, Lipsett M, Guo Y, Kopchick JJ, Kumar U, Liu YL (2004) Disruption of growth hormone receptor gene causes diminished pancreatic islet size and increased insulin sensitivity in mice. Am J Physiol Endocrinol Metab 287:E405-E413. doi:10.1152/ ajpendo.00423.2003

Masternak MM, Al-Regaiey KA, Del Rosario Lim MM, Jimenez-Ortega V, Panici JA, Bonkowski MS, Kopchick JJ, Wang Z, Bartke A (2006) Caloric restriction and growth hormone receptor knockout: effects on expression of genes involved in insulin action in the heart. Exp Gerontol 41:417-429. doi:10.1016/j.exger.2006.01.009

Mishra R, Emancipator SN, Kern T, Simonson MS (2005) High glucose evokes an intrinsic proapoptotic signaling pathway in mesangial cells. Kidney Int 67:82-93. doi:10.1111/ j.1523-1755.2005.00058.x

Miyazawa M, Ishii T, Yasuda K, Noda S, Onouchi H, Hartman PS, Ishii N (2009) The role of mitochondrial superoxide anion $\left(\mathrm{O}_{2}^{-}\right)$on physiological aging in $\mathrm{C} 57 \mathrm{BL} / 6 \mathrm{~J}$ mice. $\mathrm{J}$ Radiat Res 50:73-82. doi:10.1269/jrr.08097

Moien-Afshari F, Ghosh S, Khazaei M, Kieffer TJ, Brownsey RW, Laher I (2008) Exercise restores endothelial function independently of weight loss or hyperglycemic status in $d b / d b$ mice. Diabetologia 51:1327-1337. doi:10.1007/ s00125-008-0996-x

Murata Y, Rydevik B, Nannmark U, Larsson K, Takahashi K, Kato Y, Olmarker K (2010) Local application of interleukin-6 to the dorsal root ganglion induces tumor necrosis factor-alpha in the dorsal root ganglion and results in apoptosis of the dorsal root ganglion cells. Spine. doi:10.1097/BRS.0b013e3181e7f4a9

Muzumdar R, Allison DB, Huffman DM, Ma X, Atzmon G, Einstein FH, Fishman S, Poduval AD, McVei T, Keith S, Barzilai N (2008) Visceral adipose tissue modulates mammalian longevity. Aging Cell 7:438-440. doi:10.1111/j.1474-9726.2008.00391.x

Ortiz A, Ziyadeh FN, Neilson EG (1997) Expression of apoptosis-regulatory genes in renal proximal tubular epithelial cells exposed to high ambient glucose and in diabetic kidneys. J Investig Med 45:50-56

Percy CJ, Power D, Gobe GC (2008) Renal ageing: changes in the cellular mechanisms of energy metabolism and oxidant handling. Nephrology 13:147-152. doi:10.1111/j.14401797.2008.00924.x

Salmon AB, Murakami S, Bartke A, Kopchick JJ, Yasumura K, Miller RA (2005) Fibroblast cell lines from young adult mice of long-lived mutant strains are resistant to multiple forms of stress. Am J Physiol Endocrinol Metab 289:E23E29. doi:10.1152/ajpendo.00575.2004

Shi H, Strader AD, Woods SC, Seeley RJ (2007) The effect of fat removal on glucose tolerance is depot specific in male and female mice. Am J Physiol Endocrinol Metab 293: E1012-E1020. doi:10.1152/ajpendo.00649.2006

Sishi BJN, Engelbrecht A-M (2011) Tumor necrosis factor alpha (TNF- $\alpha)$ inactivates the PI3-kinase/PKB pathway and induces atrophy and apoptosis in L6 myotubes. Cytokine. doi:10.1016/j.cyto.2011.01.009

Sun LY, Steinbaugh MJ, Masternak MM, Bartke A, Miller RA (2009) Fibroblasts from long-lived mutant mice show 
diminished ERK1/2 phosphorylation but exaggerated induction of immediate early genes. Free Radic Biol Med 47:1753-1761. doi:10.1016/j.freeradbiomed.2009.09.021

Tao Y, Kim J, Faubel S, Wu JC, Falk SA, Schrier RW, Edelstein CL (2005) Caspase inhibition reduces tubular apoptosis and proliferation and slows disease progression in polycystic kidney disease. Proc Natl Acad Sci USA 102:6954-6959. doi:10.1073/pnas.0408518102

Tao Y, Zafar I, Kim J, Schrier RW, Edelstein CL (2008) Caspase-3 gene deletion prolongs survival in polycystic kidney disease. J Am Soc Nephrol 19:749-755. doi:10.1681/ASN.2006121378

Wang Z, Havasi A, Gall JM, Mao H, Schwartz JH, Borkan SC (2009) $\beta$-catenin promotes survival of renal epithelial cells by inhibiting bax. J Am Soc Nephrol 20:1919-1928. doi:10.1681/ASN.2009030253

Yang H, Fogo AB (2010) Cell senescence in the aging kidney. J Am Soc Nephrol 21:1436-1439. doi:10.1681/ASN.2010020205

Zhang HH, Kumar S, Barnett AH, Eggo MC (2001) Dexamethasone inhibits tumor necrosis factor-alpha-induced apoptosis and interleukin-1 beta release in human subcutaneous adipocytes and preadipocytes. J Clin Endocrinol Metab 86:2817-2825. doi:10.1210/jc.86.6.2817

Zhang X, Zheng X, Sun H, Feng B, Chen G, Vladau C, Li M, Chen D, Suzuki M, Min L, Liu W, Garcia B, Zhong R, Min WP (2006) Prevention of renal ischemic injury by silencing the expression of renal caspase 3 and caspase 8 . Transplantation 82:1728-1732. doi:10.1097/01. tp.0000250764.17636.ba

Zheng F, Cheng Q-L, Plati A-R, Ye SQ, Berho M, Banerjee A, Potier M, Jaimes EA, Yu H, Guan Y-F, Hao C-M, Striker LJ, Striker GE (2004) The glomerulosclerosis of aging in females: contribution of the proinflammatory mesangial cell phenotype to macrophage infiltration. Am J Pathol 165:1789-1798

Zhou Y, Xu BC, Maheshwari HG, He L, Reed M, Lozykowski M, Okada S, Cataldo L, Coschigano K, Wagner TE, Baumann G, Kopchick JJ (1997) A mammalian model for Laron syndrome produced by targeted disruption of the mouse growth hormone receptor/binding protein gene (the Laron mouse). Proc Natl Acad Sci USA 94:13215-13220 